\title{
Originalia
}

Thorsten Arens*

\section{Muslim doctors in Catholic hospitals: a challenge for the Christian profile?}

\author{
Muslimische Ärzte in katholischen Krankenhäusern: Eine Herausforderung für das \\ christliche Profil? ${ }^{1}$
}

https://doi.org/10.1515/spircare-2018-0046

Vorab online veröffentlicht 22. Juni 2019

\begin{abstract}
The increased immigration in Germany since 1949 has resulted in around four million Muslims settling there. Some of them are employed by churches, particularly as doctors in Catholic hospitals. At the same time, church leaders are demanding a clear, recognisable Christian profile for these institutions. What does this mean and what are the resulting challenges for the Christian profile with regard to a Muslim workforce? These highly topical and hitherto scientifically unanswered questions have been addressed in a qualitative study, in which the answers of six Catholic and six Muslim physicians with different medical specialisations in different Caritas hospitals are assigned to the categories of the three-level-model of the Christian profile. Among other things, the evaluations lead to the following result: Neither the coexistence of Catholic and Muslim physicians nor the headscarves of Muslim women prove to be a challenge in hospitals. It is rather framework conditions in the healthcare system that create problems and conflict with Christian requirements. One of the final recommendations is therefore that the people responsible for the framework provide conditions in which Catholic and Muslim physicians can credibly fulfil the requirements of the Christian mission. The results of the study also illustrate the necessity for a constant thematisation of the Christian foundation of faith as well as of church employment law. Therefore, physicians are able to understand, support and discuss Christian ideas on norms and morals as well as church framework requirements.
\end{abstract}

1 This work won the IGGS Research Award 2018. It was published in 2018 as: "Christliches Profil und muslimisches Personal. Katholische und muslimische Ärzte in Caritas-Krankenhäusern" by Kohlhammer, Stuttgart.

*Korrespondenzautor: Thorsten Arens, Neuss,

E-Mail: kontakt@thorsten-arens.de
Keywords: Diaconia, interreligious dialogue, Christian profile, denominational hospital, corporate culture

Zusammenfassung: Mit der vermehrten Zuwanderung von Migranten in Deutschland seit 1949 sind auch rund vier Millionen Muslime sesshaft geworden, von denen einige bei den Kirchen arbeiten - unter anderem als Ärzte in katholischen Krankenhäusern. Gleichzeitig fordern Kirchenverantwortliche ein klares, erkennbares christliches Profil dieser Einrichtungen. Was bedeutet das, und welche Herausforderungen ergeben sich im Blick auf muslimische Mitarbeitende? Diesen hochaktuellen und bislang wissenschaftlich unbeantworteten Fragen wird alltagsnah im Rahmen einer qualitativen Studie nachgegangen, indem die Antworten von sechs katholischen und sechs muslimischen Assistenz-, Ober- und Chefärzten unterschiedlicher medizinischer Fachrichtungen aus Caritas-Krankenhäusern den Kategorien des Drei-Ebenen-Modells des christlichen Profils zuordnet werden. Demnach begründen sich katholische Krankenhäuser erstens vom christlichen Glauben her, weshalb das christliche Gottes-, Menschen- und Werteverständnis fundamental für sie sind. Zweitens sind katholische Krankenhäuser katholische Kirche, so dass das Verständnis der katholischen Kirche als Glaubens- und Arbeitsorganisation für sie zentral sind. Drittens verfolgen katholische Krankenhäuser den Anspruch, in ihren Strukturen und Kulturen glaubwürdig und spürbar christlich zu sein, in der Art wie menschliche Beziehungen gelebt werden (koinonia), in der Art wie im Alltag die frohe Botschaft des christlichen Glaubens in Tat und Wort bezeugt wird (martyria), in der Art wie die Beziehungen $\mathrm{zu}$ Gott erfahren und gefeiert werden (liturgia) und schließlich in der Art wie menschlicher Not ganz konkret begegnet wird (diakonia). Die Auswertungen führen u. a. zu dem Ergebnis: Egal ob mit Kopftuch oder ohne, das Mit- und Nebeneinander von katholischen und muslimischen Ärzten stellt im Krankenhausalltag keine Herausforderung dar, vielmehr sind es die Rahmenbedingungen des Gesundheitswesens, die Probleme bereiten und mit 
dem christlichen Anspruch in Konflikt geraten. Die Studienergebnisse verdeutlichen darüber hinaus die Notwendigkeit einer stetigen Thematisierung des christlichen Glaubensfundaments sowie des kirchlichen Arbeitsrechtes - mit dem Ziel, dass christliche Norm- und Moralvorstellungen sowie kirchliche Rahmenvorgaben nachvollzogen, mitgetragen und offen zur Sprache gebracht werden können. Die zentrale Erkenntnis dieser Studie: Muslimische Ärzte können durch ihre Fragen zum Impulsgeber zur Auseinandersetzung mit dem eigenen Christsein werden, wodurch sie einen zentralen Beitrag zur Schärfung des christlichen Profils leisten.

Schlüsselwörter: Diakonie, Interreligiöser Dialog, Christliches Profil, Konfessionelles Krankenhaus, Unternehmenskultur

\section{Muslims in church institutions and the demand for a Christian profile}

At the end of 2014, around 1.2 million people in Germany worked in hospitals, 14.4 percent of them in the medical service (Deutscher Ethikrat 2016). It is statistically unknown how many of the approximately four million Muslims living in Germany (Bertelsmann Foundation 2016) have found jobs in the medical service of Catholic hospitals. It is generally estimated that many thousands of dissidents work in church institutions (Ebertz 2014). The basis for the employment of Muslims in the Catholic Church was created with the Second Vatican Council in 1965 in the document Nostra Aetate. Therein, the church declared its readiness for interreligious dialogue with Islam on the common basis of belief in One God and in Abraham. The consequence is that Caritas - and thus also the teams of doctors - became religiously pluralistic (Ebertz \& Segler 2016). At the same time, Pope Francis reminded all German bishops during the ad limina visit on 20.11.2015 in Rome:

\footnotetext{
All over the world, the Church is professionally engaged in the social-charitable field and is also extremely active within the school system. Care must be taken to ensure that the Catholic profile is safeguarded in these institutions (Sekretariat der Deutschen Bischofskonferenz 2015: 1, own translation of the German quotation).
}

This demand reminds indirectly of Benedict XVI, who in a Motu proprio in 2012 assigned the ultimate responsibility, support and control for charitable initiatives and organisations to the bishops (Benedikt XVI 2012: Articles 4 and 6).
In addition to the recognition of the church character and the intercultural competences of the employees, the German bishops link the employment of non-church employees in Catholic institutions to a

[...] clear Catholic profile [...], which [...] is not only anchored in mission statements and concepts but is also implemented in form of Christian culture within the institutions and brought to life by the employees (Die Deutschen Bischöfe 2014: 36, own translation of the German quotation).

Despite the fact that the literature on the Christian profile of church institutions is unspecific, unclear and multifaceted and illustrates the current confusion as to what the Christian profile of a Catholic hospital might be (Berg 2015; Nauer 2015), the aspects discussed among scholars lead to the realisation that the Christian profile of Catholic hospitals can be described on the basis of three levels (Arens 2018): first and foremost, Catholic hospitals are based on the Christian faith - the Christian understanding of God, man and values are fundamental to them. Secondly, Catholic hospitals are part of the Catholic Church, the understanding of the Catholic Church as an organisation of faith and work is central to them. Thirdly, Catholic hospitals endeavour to be credible and perceptibly Christian in their structures and culture: this is reflected in the way people interact and build relationships (koinonia), in how they bear witness to the Christian faith in word and deed (martyria), in how they celebrate their relationship with God (liturgia), and finally in how they help people in distress (diakonia). These three levels of the Christian profile are closely interlinked. They belong together organically and validate each other. The questions in relation to Muslim physicians in Catholic hospitals are: what sort of challenges do the employment of Muslim physicians pose for the three levels of the Christian profile? What needs to be done in order to maintain, strengthen and develop a Christian profile in Catholic hospitals? The fact that these questions remain scientifically unanswered is confirmed by the religious scientist Alexander Nagel:

Questions of interreligious and intercultural openness have been discussed within denominational welfare associations for quite some time. The academic debate on religious and cultural pluralisation as a challenge and opportunity for deaconry and charity, on the other hand, is still in its infancy (Nagel 2016: 122, own translation of the German quotation).

\section{Research method}

Since physicians play an important role in the maintenance of Christian culture in a hospital, particular focus 
was given to the points of view of Catholic and Muslim physicians in a qualitative study, under equal consideration of both sexes. The relevant data were collected by means of semi-structured interviews with local experts at the hospital and then evaluated using qualitative content analysis and assigned to the categories of the three-level-model of the Christian profile. The following questions were examined in more detail: What do Catholic and Muslim physicians think about religious beliefs in general and about the different religious beliefs of others in particular? What do Catholic and Muslim physicians think about their choice of the Catholic Church as their employer? What do they think about the application of Church guidelines regarding their employment as well as career options for Muslims? What do Catholic and Muslim physicians think about the Christian mission statement and about the Christian culture of their institution? Based on this, the following research question was answered: Which are the challenges the employment of Muslim physicians poses for the three levels of the Christian profile? What has to be done in order to maintain, strengthen and develop the Christian profile of Catholic hospitals? In the study, 19 persons from different disciplines were interviewed during the period from 29.08.2013 to 15.10.2014. Seven of these were test interviews. The interviews lasted between 46 and 84 minutes. The interview participants were selected at random: the only criteria were religious affiliation and employment at a Catholic hospital. The interviews were conducted in four different hospitals in the German dioceses Essen and Limburg as well as the archdiocese Paderborn. The evaluation included a total of six conversations with Muslim physicians, three of whom were male, and three female. Two of the female staff wore a headscarf. Corresponding numbers of Catholic physicians were also interviewed, three male, and three female.

The following findings are a section of the whole study, which is published in the German book "A Christian profile and Muslim staff. Catholic and Muslim physicians in hospitals of the Caritas" (Arens 2018, own translation of the German title). Included in this publication are also statements by Catholic and Muslim physicians which are presented and discussed in detail. The way the results are presented is based on the three levels of the Christian profile described above.

\section{Summary of the findings of the qualitative study}

\subsection{With regard to the first profile level: based on the Christian foundation of faith}

According to the physicians interviewed for the study, the different conceptions of God Christians and Muslims have do not present a challenge in day-to-day hospital life. It is striking that none of the Catholic physicians describe their Christian understanding of God in all its complexity: compared to Muslims, Catholics explicitly fail to say anything about the Trinity of God. When all statements by Catholics are taken into consideration, the understanding of God as Father, Son and Holy Spirit does however become apparent. Muslim doctors on the other hand speak explicitly about the Trinity and explain that Jesus is unthinkable for them as the Son of God because of God's omnipresence and immortality. The Christian image of man is unknown to most Muslim as well as Catholic physicians, only a minority can comment on it at all. The Muslim interviewees do, however, know how to talk about their own religious image of man. Both Catholic and Muslim physicians say that they have common values on the basis of similar views of God and man, which are substantiated by common norms and ethical standards. The interviewees say that they have a common mission of practiced charity, even if it is based on different contexts: Bible and Quran.

\subsection{With regard to the second profile level: living within the Catholic Church}

None of the doctors interviewed had searched specifically for a Catholic hospital as an employer: they found them because of the proximity to the applicant's home or to their family. During their job interviews, Catholics were hardly ever asked about their faith, some of the male Muslims were questioned on the topic while female Muslims were always asked about issues of their faith. It seems that for Catholics simple church membership is enough of a precondition for their employment, whereas the personal identification with faith and church does not play a role. Female Muslim physicians were always asked about the headscarf, no matter whether they wore it or not. If Muslim women wanted to wear headscarves in a Catholic hospital, this had to be approved within the organisation first. Muslim interviewees are aware that they are not allowed to promote their own faith in Catholic hospitals. The hospitals included in the study showed a high degree of open- 
ness towards the employment of Muslims: the physicians who were interviewed did not see any issues as to the employment of Muslims in Catholic hospitals, as long as Christian faith was practiced within the institution, and also was represented recognisably and appropriately to the outside world. At the time of the interviews, the church employment law had not yet been revised. One Catholic perceived the older version as restrictive - other persons did not even bring up the topic during the conversation. It became obvious that the Muslim staff who were interviewed were not informed about their limited career opportunities in Catholic hospitals. Catholic physicians also have varying views in this regard.

\subsection{With regard to the third profile level: credible and perceptibly Christian culture}

Many of the interviewees do not know the mission statement of their Catholic hospital. Those who know it cannot find anything positive in it, because in reality they experience economic pressure, performance pressure, lack of information, lack of appreciation as well as shortage of personnel, time and workspace, all of which lead to stress, work overload, excessive demands and diminished quality of care for employees. Muslims as well as Catholics worry that church hospitals are becoming increasingly similar to non-faith institutions. Therefore, as a result of the dwindling presence of Brothers and Sisters belonging to the Christian order in ecclesiastical hospitals, some doctors have recognised that the implementation of a Christian culture is now a secular task. A head physician expresses the hope that this task might be taken on by the nursing staff, rather less so by physicians.

In everyday life doctors do not have time to talk about religion and faith. Doctors primarily recognise Christianity in tangible things like crosses, pastors or the celebration of Holy Mass. Muslim interviewees do not associate their work as medics with their own faith; their focus is on professionalism. Some of the interviewed Catholics and Muslims see the beginnings of interreligious understanding in helping people. Respondents also reported that Muslim women who wear headscarves experience positive as well as negative reactions from patients. They also have to do more to prove themselves in everyday medical life than doctors without headscarves. Therefore, Muslim women with headscarves say that they need a good deal of selfconfidence so that they do not find themselves cornered by comments or forced into a defensive position. Overall, the headscarf was not a problem in the hospitals included in this study. There were no women wearing burqa.
Catholics are unsure whether or how Muslims practice their faith at work. One Catholic interviewee saw it as a potential problem if a Muslim physician decided to participate in Friday prayers without finishing all his work first. None of the interviewed Muslims consider praying in public an option which is why a majority of Muslim physicians pray in the doctor's room - also because Muslim prayer rooms are not always available. Even if they are, doctors are often not aware of them. It is a great challenge for Muslim doctors in hospitals to practice the Ramadan because fasting has negative effects on work performance. A Catholic doctor in charge of the rota reacts with understanding and allows a Muslim colleague to work half days at the weekend.

The interviewed physicians state that their focus is on satisfying patients' needs, including those who are poor and not insured. For Catholic doctors a holistic approach to medicine is important in which social, religious and pastoral aspects also play a role. Physicians report of vacant pastoral positions as well as extensive pastoral tasks, therefore it is often difficult for them to find a person to speak to. This is seen as a significant shortcoming with regard to the Christian profile of the hospital. They also talk about the lack of specific pastoral care for Muslims, meaning that this role is occasionally taken over by Christian pastoral staff, doctors or family members. A Catholic palliative physician is of the opinion that all occupational groups in the hospital are also pastoral workers. A Muslim physician, however, feels that this task is beyond him.

\section{Discussion}

In the following chapter, some central aspects of the study are discussed exemplarily and without claim to completeness.

\subsection{With regard to the first profile level: based on the Christian foundation of faith}

The answers given by Catholic physicians about their understanding of God give rise to the following questions: is the Christian view of God too complex to be discussed easily? Or do issues arise from the fact that, as the Würzburg study realised, one in ten Caritas employees rejects the idea of a personal as well as non-personal image of God (Ebertz \& Segler 2016)? Are Christians not able to talk about God because the necessary knowledge and vocabulary have been lost? Or are there other reasons? The habilitated theologian Joachim Wiemeyer demands that "even non-Catho- 
lic employees [...] have to know (cognitively) something about the Catholic faith in order to be able to deal with Catholic clients accordingly" (Wiemeyer 2016: 85-86, own translation of the German quotation). With regard to the result that Muslims already know many aspects of the Christian image of God, one has to ask what else they need. When physicians were asked about the Christian concept of man in this study, Muslims and Catholics were equally speechless. The reasons given were a lack of debate about the topic as well as lost religious context. Is it not also possible to assume that many people's relationship with the faith of the church has become a selective one, because they no longer perceive and accept certain parts of the truth of faith as plausible (Ebertz \& Segler 2016)? For the medical director of the Association of Catholic Clinics, Theodor Königshausen, this points to a fundamental issue:

the question arises [...] whether the inalienable positions of the Christian view of man in a Catholic/Christian hospital, on which base the institutions justify their right to exist, can still be guaranteed in a plural society (Königshausen 2016: 15, own translation of the German quotation).

A possible solution might be to create spaces in Catholic hospitals where the Christian understanding of man, God and values could be discussed with others. The results of this study show that the number of common values is extensive, therefore Christians and Muslims form a community of values. The Central Committee of German Catholics underlines this in 2012:

The similarities in the image of man, in the understanding of God and in ethics clearly show that Christians and Muslims also have a common mission in and for society, for the well-being of all people, individuals as well as the whole community (Zentralkomitee der deutschen Katholiken 2012: 13, own translation of the German quotation).

\subsection{With regard to the second profile level: living within the Catholic Church}

A Muslim doctor reports that it is not easy for Muslims to pursue a career in Catholic hospitals. Catholic physicians confirm this point of view: Muslims can only become senior physicians but not head physicians in German Christian hospitals. Neither Catholic nor Muslim physicians are certain whether this is actually the case. This prompts the question whether Muslims are familiar with church employment law and their career opportunities (Ari 2010). Do employers talk about these issues openly and transparently? A study by the Technical Universities in Berlin and Dortmund, in which more than 100 Christian hospitals participated, demonstrates that 72 percent of hospitals filled leadership positions with staff who identify with Christian values (Osterloh 2016). A study by the Caritas Association in Münster comes to the conclusion that "formal characteristics, such as church membership of employees, are of minor importance for the Christian profile of the hospital" (Caritasverband für die Diözese Münster e.V. 2015: 6, own translation of the German quotation). The so-called Brussels Circle, an association of 13 non-profit social and health economic institutions from Caritas and Diakonie, is convinced that church membership becomes a condition that can hardly be fulfilled with regard to the manifold secularisation tendencies in our society (Haas \& Starnitzke 2015). Although they see church affiliation as a fundamental cornerstone that cannot be given up, they also associate challenges for the acquisition of employees with it. In times of pluralisation and secularisation, they plead in five theses for the abolition of the formal criterion of church membership as a basic condition for employment, and advocate instead a "pluralistic religious openness" and a "togetherness in diversity" with simultaneous "religious pluralism of conviction" (Haas \& Starnitzke 2015: 52-53. 56, own translations of the German quotations). Christian identity is thus not primarily maintained by the person, but by the organisation. Their vision:

\footnotetext{
The company formulates this understanding of itself towards all employees and expresses the clear expectation that they should reflect the company's ethos in their actions. In doing so, it explicitly accepts not only the various personal views of the people supported by the company, but also those of its own employees. Conversely, despite all the plurality of personal convictions, employees explicitly and bindingly acknowledge the confessional bond of the company and thus the appropriate conduct expected of them (Brüsseler Kreis 2015: 23, own translation of the German quotation).
}

Could this be a viable approach for church hospitals? The German bishops are convinced of the added value that Muslims and other believers can bring to Catholic institutions: "In justified individual cases, charitable institutions therefore employ non-Christian employees with their own migration backgrounds and find that this enriches their work" (Die Deutschen Bischöfe 2014: 27, own translation of the German quotation).

\subsection{With regard to the third profile level: credible and perceptibly Christian culture}

Respondents of these and other studies experience that framework conditions at work are not conducive to the im- 
plementation of a Christian ethos by physicians. They see this as a contradiction to the mission statement. Theologian Hans Hobelsberger (2016) is convinced that the mission statement loses its affirmative and orientating function, is ultimately regarded as an ideological value, and can even have a counterproductive effect. The excessive focus on economic profitability also leads to the fact that the Christian view of man is in danger of getting lost because under these circumstances, pauses, attention, listening, appreciation, etc. can no longer be guaranteed. Further studies confirm this and see this development increasingly as a consequence of the introduction of DRGs (Deutscher Ethikrat 2016). In the Würzburg study, employees are convinced that a spiritual profile can only succeed if the organised Caritas does not ignore the work on the quality of interaction between the helpers and their addressees, which is what Caritas should be based on after all (Ebertz \& Segler 2016). Suitable framework conditions also play an important role in enabling an exchange about faith and religion at work. However, the Muslims questioned report that they understand religion as a private matter and that their own faith does not play a central role in helping others. This is not surprising since they were told in their first interview with the employer that their Muslim faith must not be lived publicly at the hospital. Nevertheless, Muslim as well as Catholic interviewees experience that they share the same basic attitude and practice charity. This shows that, in terms of their day-to-day actions, they focus on common goals. This can be affirmed with Dorothee Steiof, who is convinced that "people can act in the spirit of the gospel, even if their motivation for this service comes from another faith orientation or world view" (Steiof 2016: 160, own translation of the German quotation). For Ottmar Fuchs such action is an action "with the Church in favour of a certain common goal, which the Church understands from its identity as a concrete expression of the Kingdom of God" (Fuchs 2009: 268, own translation of the German quotation). For Fuchs, this is not an appropriation but an ability to form alliances for the Kingdom of God and for human beings. How can this common idea of aid be made successful in terms of serving others especially regarding spiritual care: a Muslim physician reports that there is no provision of pastoral care for Muslims. One idea is that Muslim physicians can do this job, but one Muslim physician indicates that this task is beyond his capabilities. A study of Turkish physicians shows that "the majority of medical staff $(84.4 \%)$ [...] rarely or never ask about spiritual/religious concerns of patients or their families" (Kuseyri 2018: 37, own translation of the German quotation). The chairman of the Catholic Hospital Association of Germany, Theo Paul, says that doctors do not need to be able to practice pastoral care, but they have to be sensitive to it (Paul 2017). According to results of a study by Volker Meißner (2014), there are just isolated model projects of Muslim pastoral care: the treaties between the states of Hamburg and Bremen and Muslim organisations from the year 2013 created a basis on which religious facilities in hospitals of both states could be developed. This could send a signal to other federal states to follow suit. Carla Amina Baghajati, the women's representative of the Islamic Religious Community in Austria, provides a rather more sobering assessment:

We are still only able to speak about the issue in the subjunctive because in reality we are still a long way away from any kind of institutionalised Muslim pastoral care in hospitals in the German-speaking area, even if the need for it is undisputed (Baghajati 2014: 239, own translation of the German quotation).

It therefore seems that the question of how pastoral care for Muslim patients and staff can be ensured remains unanswered. There is also another important question: how can the use of headscarves be handled across all Catholic hospitals, since attitudes can vary from one hospital to another? In some hospitals female Muslim doctors are allowed to wear headscarves (Meißner 2014), but in other hospitals the wearing of headscarves is forbidden. In an interview with the French daily "La Croix" on 16 May 2016, Pope Francis spoke out against such a ban and for the freedom to express one's faith: "If a Muslim woman wants to wear a headscarf she must be able to do so, just like a Catholic who wants to wear a cross" (quoted from the Katholische Nachrichten Agentur 2016, own translation of the German quotation). Does this also apply to Catholic hospitals?

\section{Overall conclusion and outlook}

In view of the initial question and the results of this study, it can be said that Muslim physicians represent an enrichment for Catholic hospitals. The daily cooperation between Catholic and Muslim doctors who provide care for people in need works smoothly; the coexistence of both faiths does not present a problem either. It is rather the framework conditions which make it difficult to live up to Christian aspirations because of the density and volume of work. It is necessary to eliminate these problems: beyond the political commitment of church hospitals, creative and courageous solutions are needed. A scientific approach can be a worthwhile tool in solving these challenges, as can pastoral theological research on the practical imple- 
mentation of interreligious dialogue in Catholic hospitals. In addition, there are scientific assignments in dogmatism, moral theology and social ethics aimed at developing ways in which the basic principles of the Second Vatican Council can be reinforced in order to become real foundations for church practice at all three levels of the Christian profile.

\section{Forschungsförderung: Keine.}

Einwilligungserklärung: Einwilligungserklärungen wurden von allen Studienteilnehmern eingeholt.

Erklärung zur ethischen Zulassung: In Übereinstimmung mit der Deklaration von Helsinki wurden die Teilnehmer über das genaue Verfahren der Studie informiert und haben freiwillig teilgenommen.

\section{Research funding: None.}

Informed consent: Informed consent was obtained from all individuals included in this study.

Ethical approval: The research related to human use has been complied with all the relevant national regulations, institutional policies and in accordance the tenets of the Helsinki Declaration

\section{Literature}

Arens T (2018) Christliches Profil und muslimisches Personal. Katholische und muslimische Ärzte in Caritas-Krankenhäusern. Stuttgart: Kohlhammer.

Ari A (2010) Der Arbeitgeber Kirche und sein Verhältnis zu Muslimen und Konfessionslosen. Recht, Arbeitsmarkt und demographischer Wandel. Hamburg: Diplomica Verlag.

Baghajati CA (2014) Islam im Krankenhaus - Vom Umgang mit muslimischen Patientinnen und Patienten. In: Hille H (Hg.) Religiöser Pluralismus in der Klinikseelsorge. Theoretische Grundlagen, interreligiöse Perspektiven, Praxisreflexionen. Berlin: Lit-Verlag. 227-250.

Benedikt XVI. (2012) Motu Proprio über den Dienst der Liebe.

Bertelsmann Stiftung (2016) Einwanderungsland Deutschland. Factsheet. Gütersloh: Bertelsmann.

Berg P (2015) Was macht das kirchliche Profil unserer caritativen Unternehmen aus? Fachtagung am 8.10.2015. Köln: Vortragsmanuskript.

Brüsseler Kreis (2015) Die Thesen des Brüsseler Kreises. In: Haas H-S, Starnitzke D (Hg.) Diversität und Identität. Konfessionsbindung und Überzeugungspluralismus in caritativen und diakonischen Unternehmen. Stuttgart: Kohlhammer. 21-23.

Caritasverband für die Diözese Münster (2015) Das christliche Profil katholischer Krankenhäuser. Ergebnisse einer Umfrage auf Initiative der Arbeitsgemeinschaft katholischer Krankenhäuser (DiAG) im Caritasverband für die Diözese Münster e.V. (Zitierdatum: 20.09.2016), abrufbar unter https://www.caritas-muen ster.de/cms/contents/caritas-muenster.de/medien/doku mente/wir-helfen/menschen-bei-krankhe/studie-christliches/t hesen_umfrage_kkh_christlichesprofil_2015-05-26.pdf?d=a\&f= pdf

Deutscher Ethikrat (2016) Patientenwohl als ethischer Maßstab für das Krankenhaus. Stellungnahme. Berlin: Deutscher Ethikrat.

Die Deutschen Bischöfe (2014) Das katholische Profil caritativer Dienste und Einrichtungen in der pluralen Gesellschaft. Nr. 98. Bonn: Sekretariat der deutschen Bischofskonferenz.

Ebertz MN (2014) Kirche als Organisation von Organisationen. Am katholischen Beispiel. In: Heiser P (Hg.) Sozialformen der Religionen im Wandel. Wiesbaden: Springer. 169-184.

Ebertz MN, Segler L (2016) Spiritualitäten als Ressource für eine dienende Kirche. Die Würzburg-Studie. Würzburg: Echter.

Fuchs $O$ (2009) Caritaseinrichtungen als Orte interreligiöser Praxis. Theologische Quartalschrift 4:262-273.

Haas H-S, Starnitzke D (2015) Diversität und Identität. Konfessionsbindung und Überzeugungspluralismus in caritativen und diakonischen Unternehmen. Stuttgart: Kohlhammer.

Hobelsberger H (2016) Innere Leitbilder von Akteuren im Krankenhaus in Medizin und Pflege. In: Hüster P, Hobelsberger $\mathrm{H}$, Hellwig A ( $\mathrm{Hg}$.) Christliche Organisationskultur prägen. Freiburg i. Br.: Lambertus. 49-86.

Katholische Nachrichten Agentur (2016) Laizität nicht übertreiben. Papst gegen Kopftuchverbot. (Zitierdatum 08.01.2017), abrufbar unter https://www.domradio.de/themen/papst-franziskus/201 6-05-17/papst-gegen-kopftuchverbot

Königshausen T (2016) Katholische Kliniken - zwischen Caritas und Commerz. Veranstaltung vom 20.07.2016. Düsseldorf: Vortragsmanuskript.

Kuseyri C (2018) Türkischstämmige Gesundheitspersonen in Deutschland: Der Diaspora-Effekt. Spiritual Care 7: 33-44.

Meißner V (2014) In schwierigen Lebenssituationen Gott zur Sprache bringen - Seelsorge und religiöse Begleitung. In: Meißner V, Affolderbach M, Mohagheghi H, Renz A (Hg.) Handbuch christlich-islamischer Dialog. Grundlagen - Themen - Praxis Akteure. Freiburg i. Br.: Herder. 280-288.

Meißner V (2014) Werte in Institutionen und Organisationen. Lernort Krankenhaus. In: Freise J, Khorchide M (Hg.) Wertedialog der Religionen. Überlegungen und Erfahrungen zu Bildung, Seelsorge, Sozialer Arbeit und Wissenschaft. Freiburg: Herder. 234-250.

Nagel A (2016) Zwischen Anwaltschaft und Selbstbehauptung. Zur Außendarstellung konfessioneller Wohlfahrtsverbände angesichts religiöser Pluralisierung. Jähnichen T, Nagel A-K, Schneiders K (Hg.) Religiöse Pluralisierung: Herausforderung für konfessionelle Wohlfahrtsverbände. Stuttgart: Kohlhammer. 111-131.

Nauer D (2015) Spiritual Care statt Seelsorge? Stuttgart: Kohlhammer. Osterloh F (2016) Seelsorge als Mehrwert im Wettbewerb. Deutsches Ärzteblatt 26:1247.

Paul T (2017) Grußwort. Krankenhausseelsorge der Zukunft. KKVD aktuell 1:1-2.

Sekretariat der Deutschen Bischofskonferenz (2015) Ansprache S. H. Papst Franziskus bei der aus Anlass des Ad-liminaBesuchs gewährten Audienz für die deutschen Bischöfe in Rom am 20. November 2015. (Zitierdatum: 20.11.2015), abrufbar unter http://www.dbk.de/fileadmin/redaktion/diverse_down loads/presse_2015/2015-221a-Ad-limina-Ansprache-Papst-Fran ziskus.pdf 
Steiof D (2016) Die Gestaltung von religiöser und weltanschaulicher Vielfalt in der Dienstgemeinschaft eines karitativen Trägers. Praxiserfahrungen und Lernprozesse beim DiCV Rottenburg-Stuttgart. In: Jähnichen T, Nagel A-K, Schneiders K (Hg.) Religiöse Pluralisierung: Herausforderung für konfessionelle Wohlfahrtsverbände. Stuttgart: Kohlhammer. 151-164.

Wiemeyer J (2016) Caritas und interkulturelle Öffnung. Jähnichen T, Nagel A-K, Schneiders K (Hg.) Religiöse Pluralisierung: Herausforderung für konfessionelle Wohlfahrtsverbände. Stuttgart: Kohlhammer. 65-87.

Zentralkomitee der Deutschen Katholiken (2012) Christen und Muslime - Partner in der pluralistischen Gesellschaft. Eine gemeinsame Auseinandersetzung mit gesellschaftlichen Fragen. Bonn: ZdK.
Zweites Vatikanisches Konzil (1965) Nostra Aetate. Über das Verhältnis der Kirche zu den nichtchristlichen Religionen. (Zitierdatum 03.05.2015), abrufbar unter http://www.vatican.v a/archive/hist_councils/ii_vatican_council/documents/vat-ii_ decl_19651028_nostra-aetate_ge.html

\section{Biografische Angaben}

\section{Thorsten Arens}

Dr., ist in der St. Augustinus Gruppe Referent für die Schwerpunkte christliche Profilbildung, Ethik, Seelsorge, Spiritualität und christliches Management. Er ist Lehrbeauftragter für Theologie im Fachbereich Gesundheitswesen an der Katholischen Hochschule NRW, Abteilung Köln. 